Florida International University FIU Digital Commons

6-23-1995

\title{
Effects of inconsistencies in eyewitness testimony on mock-juror decisionmaking
}

Garrett L. Berman

Florida International University

DOI: $10.25148 /$ etd.FI14051114

Follow this and additional works at: https://digitalcommons.fiu.edu/etd

Part of the Applied Behavior Analysis Commons

\section{Recommended Citation}

Berman, Garrett L., "Effects of inconsistencies in eyewitness testimony on mock-juror decisionmaking" (1995). FIU Electronic Theses and Dissertations. 1627.

https://digitalcommons.fiu.edu/etd/1627

This work is brought to you for free and open access by the University Graduate School at FIU Digital Commons. It has been accepted for inclusion in FIU Electronic Theses and Dissertations by an authorized administrator of FIU Digital Commons. For more information, please contact dcc@fiu.edu. 


\title{
FLORIDA INTERNATIONAL UNIVERSITY
}

Miami, Florida

\author{
Effects of Inconsistencies in Eyewitness Testimony \\ on Mock-Juror Decisionmaking
}

A dissertation submitted in partial satisfaction of the requirements for the degree of

DOCTOR OF PHILOSOPHY

IN

PSYCHOLOGY

by

Garrett L. Berman

1995 


\section{DISSERTATION COMMITTEE APPROVAL SHEET}

To: Dean Arthur W. Herriott

College of Arts and Sciences

This dissertation, written by Garrett Lee Berman, and entitled Effects of Inconsistencies in Eyewitness Testimony on Mock-Juror Decisionmaking, having been approved in respect to style and intellectual content, is referred to you for judgement.

We have read this dissertation and recommend that it be approved.

Fred Newman

Scott Fraser

Ronald P. Fisher

$\overline{\text { Brian L. Cutler, Major Professor }}$

Date of Defense: June 23, 1995

This dissertation of Garrett Lee Berman is approved.

Dean Arthur W. Herriott

College of Arts and Sciences

Richard L. Campbell

Dean of Graduate studies

Florida International University, 1995 


\section{ACKNOWLEDGMENTS}

I would like to thank Tanya Castiglione and Maria Borras for their assistance in developing stimulus materials and data collection. A special thanks to my major professor Brian L. Cutler for his time, patience, and encouragement. I would also like to thank Ronald Fisher, Scott Fraser, and Fred Newman who as members of my dissertation committee provided encouraging comments. Finally, this dissertation would not have been possible without the love and support of my parents and friends. 
ABSTRACT OF THE DISSERTATION

Effects of Inconsistencies in Eyewitness Testimony on Mock-Juror Decisionmaking

by

Garrett L. Berman

Florida International University, 1995

Professor Brian L. Cutler, Major Professor

In attempting to impeach eyewitnesses, attorney's often highlight inconsistencies in the eyewitness's recall. This study examined the differential impact of types of inconsistent testimony on mock-juror decisions. Each of 100 community members and 200 undergraduates viewed one of four versions of a videotaped trial in which the primary evidence against the defendant was the testimony of the eyewitness. I manipulated the types of inconsistent statements given by the eyewitness in the four versions: (1) consistent testimony, (2) information given on-the-stand but not given during the pre-trial investigation, (3) contradictions between on-the-stand and pre-trial statements, and (4) contradictions made on the witness stand. Subjects exposed to any form of inconsistent testimony were less likely to convict and found the defendant less culpable and the eyewitness less effective. These effects were larger for contradictions than for information given on the stand but not during pre-trial investigations. 
Table of contents

DISSERTATION COMMITTEE APPROVAL SHEET • • • • • • • • • • ii

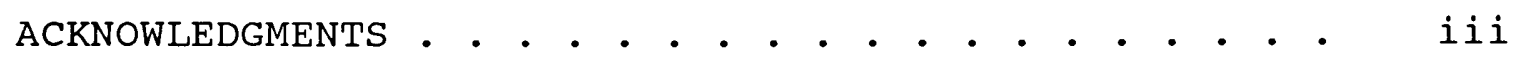

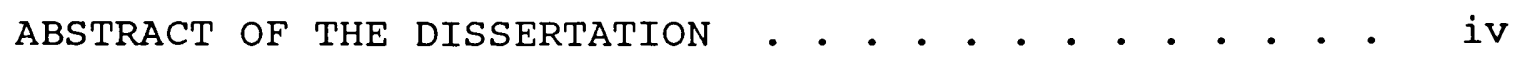

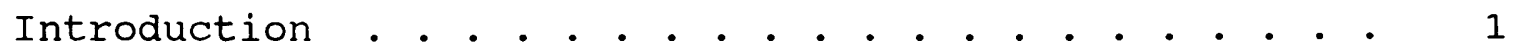

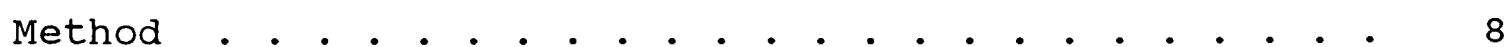

Subjects . . . . . . . . . . . . . . . . 88

Procedure . . •. . . . . . . . . . . . . . 8

stimulus Materials . . . . . . . . . . . . . . . 8

Dependant Measures . . . . . . . . . . . . . 11

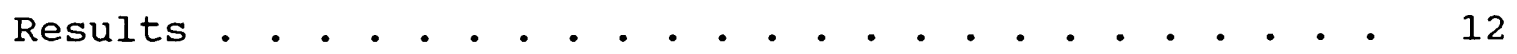

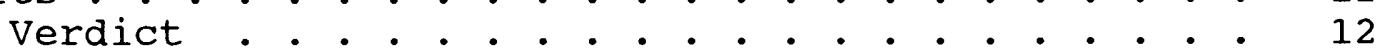

Defendant Culpability . . . . . . . . . . . 13

Effectiveness of the Eyewitness . . . . . . . . . 14

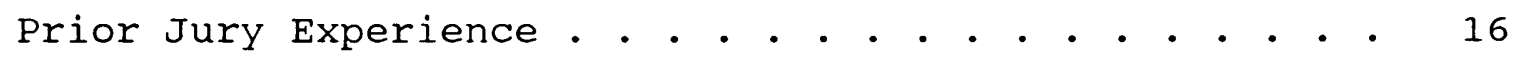

Discussion . • . . . . . . . . . . . . . . . . . 16

References . . . . . . . . . . . . . . . . . . . . 24

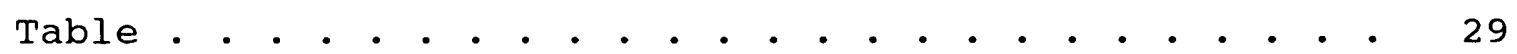

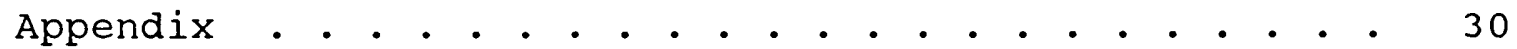

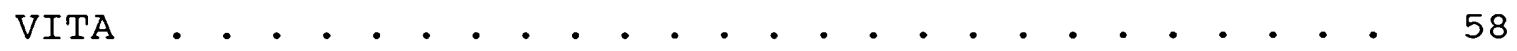


Introduction

False eyewitness identifications occur frequently in laboratory and field studies (Cutler \& Penrod, 1995) and appear to be one of the leading cause of erroneous conviction (Borchard, 1932; Brandon \& Davies, 1973; Frank \& Frank, 1957; Rattner, 1988). The legal safeguards designed to protect defendants from erroneous conviction resulting from mistaken identification include the presence of counsel at lineups (U.S. V. Wade, 1967), expert psychological testimony about human memory (People V. McDonald, 1984), and judges' instructions concerning how to evaluate eyewitness identification (U.S. V. Telfaire, 1972). The effectiveness of these safeguards is questionable. Attorneys are rarely present at their clients' lineups and, even if present, appear insensitive to some factors that influence lineup suggestiveness (Stinson, Devenport, Cutler, \& Kravitz, 1995). Expert psychological testimony on eyewitness memory is usually not admitted in court (Cutler \& Penrod, 1995; Walters, 1985). Judges' instructions on eyewitness identifications are used sporadically (Walters, 1985) and appear to not improve the quality of jurors' decisions (Cutler, Dexter \& Penrod, 1991; Greene, 1988).

Cross-examination is the most commonly used safeguard, and it is widely believed to provide defendants with sufficient protection from erroneous conviction (Walters, 
1985). Indeed, cross-examination is believed to be so effective that it is often cited as the primary reason for not invoking other safeguards, such as motions to suppress biased lineups and expert psychological testimony (Cutler \& Penrod, 1995; Walters, 1985). How effective is crossexamination as a safeguard?

In order to address this question, we must first consider how attorneys cross-examine eyewitnesses. Unfortunately, we know of no study of actual crossexaminations of eyewitnesses and only one related study of how attorneys divide their time. A job-analysis of public defenders in South Florida (Prager, Moran, \& Sanchez, 1992) revealed that identifying and eliciting inconsistencies in eyewitness testimony is a routine and important part of trial preparation. This finding coincides with advice typically found in trial practice manuals (e.g., Bailey \& Rothblatt, 1985), suggesting that, during cross-examination, attorneys should focus upon inconsistencies in the eyewitness's testimony and encourage the jury to cast doubt on the identification in light of those inconsistencies. Thus, there is some reason to believe that eliciting inconsistencies in eyewitness testimony represents a common cross-examination strategy among defense attorneys. How effective is this strategy? What do we know about the impact of testimonial inconsistencies on juror 
decisionmaking? This research focuses on these questions and, in so doing, attempts to bring data to bear on the effectiveness of cross-examination in cases involving eyewitness identification.

Using trial simulation methodology, three empirical studies have examined the effects of eyewitness inconsistency on jurors decisionmaking (Berman, Narby \& Cutler, 1995; Leippe \& Romanczyk, 1989; Lindsay, Lim, Marando, \& Cully, 1986). In each study the eyewitness testified on behalf of the prosecution, so inconsistencies in the eyewitness testimony should be associated with prodefense decisions.

Lindsay et al. (1986) investigated the impact of a series of contradictory statements about the criminal's hair color on mock-juror decisions. In the contradictory testimony condition the eyewitness testified that she originally stated that the criminal had blond hair, did not think the defendant (whom she identified from a lineup) could be described as blond, did not know if the defendant altered her hair color between the crime and lineup, recalled the defendant's hair as dark at the time of the lineup, and was certain of her identification. These statements were not given in the control condition. After listening to the audiotaped simulated trial, subjects rated the consistency of the eyewitness testimony and the guilt of 
the defendant. Contradictory statements provided by the eyewitness did not influence subjects' verdicts.

Using a written trial summary, Leippe and Romanczyk (1989) examined how subjects' decisions were influenced by inconsistent statements provided by an adult or child eyewitness. In the inconsistent testimony condition subjects were exposed to a series of statements, some of which were highlighted as contradictions between on-thestand testimony and pre-trial statements. Also included in this condition were statements made on the stand but not in pre-trial interviews. Other subjects were exposed to no inconsistent statements. Inconsistency of testimony did not significantly impact subjects' verdicts but the inconsistent child witness was seen as less credible than the consistent child witness.

Berman et al. (1995) further examined the impact of inconsistent testimony using a videotaped simulated crossexamination. They manipulated the number and type (central versus peripheral) of descriptive dimensions on which the eyewitness provided contradictory testimony. All contradictions were between on-the-stand and pre-trial statements. Subjects exposed to inconsistent eyewitness testimony perceived the eyewitness as less credible, the defendant as less culpable, and convicted the defendant less 
often. Inconsistencies in peripheral and central details produced effects of comparable magnitudes.

In conclusion, results of the three studies are mixed. The many differences between these studies makes explaining the disparate results difficult. Particularly noteworthy is the different ways in which inconsistency was operationalized. Lindsay et al. (1986) examined the influence of contradictions between an eyewitness's original description of a perpetrator (conveyed on the witness stand) and the characteristics of the person identified. Leippe and Romanczyk (1989) examined the impact of a composite manipulation consisting of two types of inconsistencies: contradictions between on-the-stand and pre-trial statements and statements given on the witness stand but not in pretrial interviews. Berman et al. (1995) assessed the impact of contradictions between on-the-stand and pre-trial statements.

It seems plausible that the impact of inconsistent testimony would vary as a function of the nature of the inconsistency, as some inconsistencies may be easier to excuse than others. There is little directly relevant social-cognitive theory upon which to draw when hypothesizing how type of inconsistency might influence juror decisionmaking. Nevertheless, we know these types of inconsistencies appear in trials (though their frequencies 
are not obvious or demonstrated empirically). My strategy is to assess whether type of inconsistency matters, and, if so, explain any differences through further experimentation. This study tests my intuitive hypothesis that the highest conviction-rate and highest ratings of defendant culpability and eyewitness effectiveness would be given by subjects exposed to (1) consistent testimony. These scores would be significantly lower for subjects exposed to (2) statements given on the witness stand that were not given during pretrial investigation, significantly lower still for subjects exposed to (3) contradictions between statements given on the witness stand and during pre-trial investigation, and significantly lower (lowest) for (4) subjects exposed to contradictions made on the witness stand.

One might reasonably ask why I am pursuing this issue given the lack of theoretical guidance from the psychological literature. One common approach to psycholegal scholarship is to test the relevance of psychological theories for legal proceedings. For example, Kassin (1985) examined the implications of social awareness theory for improving the association between eyewitness confidence and identification accuracy. Yet another approach is to identify important phenomena that have implications for both the legal system and psychology, and then later bring existing or new psychological theory to 
bear on the issue. For example, Malpass and Kravitz (1969) discovered the own-race bias in face recognition, that is, people are more accurate at recognizing faces of their own race than of other races. Research for the past two decades has (unsuccessfully) attempted to use psychological theory to explain this phenomenon. The present research is more consistent with the approach taken by Malpass and Kravitz (1969). Other approaches to psycholegal research exist as well, and the growing knowledge base will benefit from the variety of research strategies.

Last, the three previous studies relied exclusively on college undergraduates as subjects. Some (e.g., Konecni \& Ebbesen, 1979; Weiten \& Diamond, 1979) have questioned the external validity of trial simulation research that relies exclusively on college students as subjects. This study used both college students and jury-eligible community members. Use of both samples permits an empirical test of external validity: are college students and community members differentially affected by inconsistent testimony, or do the results from college students generalize to community members? Several previous trial simulation studies that have explicitly compared these samples found no significant differences in their patterns of decisions (Cutler, Dexter \& Penrod, 1989; Cutler, Penrod \& Dexter, 1990; Platania, 1995). 


\section{Method}

\section{Subjects}

The sample consisted of 300 subjects, 200 of whom were students from introductory psychology classes at a southeastern regional state university. students received course credit for their participation. The remaining 100 subjects were jury-eligible community members from the same region. Community members were selected from a variety of organizations (e.g., Jewish Community Center, Veterans Association, Elk's Lodge). In exchange for member participation the organizations were paid $\$ 3$ per participant. Each subject was randomly assigned to one of the four experimental conditions (50 students and 25 community members per condition).

\section{Procedure}

Subjects were tested in groups ranging in size from three to nine people. Upon arrival, subjects were instructed that they would be viewing a videotaped trial and to pay close attention because they would be responding to the case as if they were jurors. After viewing the videotape, subjects responded to questionnaires containing the dependent measures. Stimulus Materials

The videotaped trial lasted approximately 35 minutes. The trial was based on Berman et al.'s (1995) materials but 
was elaborated upon to include opening statements, other witnesses, closing arguments, and judges' instructions (see Appendix for trial script). Opening statements and closing arguments were similar in length and were prepared with the help of local defense attorneys. The judges' instructions were taken verbatim from the state's standard jury instructions. The defendant was charged with robbery, and the primary evidence against him was the testimony of the eyewitness who identified him as the perpetrator.

Law students from a local university played the roles of attorneys and judge. Student assistants played the roles of the witnesses. Four versions of the videotaped trial were created. The differences between the versions were limited to cross-examination of the eyewitness, and the manipulations always involved four questions about the same details of the crime. The four versions of the videotape were created by editing from a single master tape, so that each version was identical with the exception of the manipulation.

In the control, or consistent, condition, the eyewitness provided no inconsistent statements. In the remaining three conditions the eyewitness provided inconsistent statements in response to four questions in the following order for all conditions: whether the perpetrator appeared to be nervous or calm during the incident, whether 
the perpetrator threatened the eyewitness if she didn't cooperate, where the perpetrator placed the stolen money (inside his jacket pocket $v$. canvas bag), and whether the perpetrator was wearing any jewelry (gold chain $v$. no gold chain). Immediately after inconsistent testimony was given in response to one of the questions, the defense attorney confronted the eyewitness with her current and previous statements and asked which response was accurate. The eyewitness always responded with the most recent answer.

In the novel information condition, subjects were exposed to eyewitness statements highlighted by the defense attorney because they were not previously mentioned by the eyewitness during the investigation. For example, after being asked whether or not the defendant was wearing any jewelry, the eyewitness stated "yes, he was wearing a gold chain." The defense attorney responded: "how come you never mentioned any jewelry in previous depositions?" The eyewitness then responded with the recently stated information (e.g, "I remember he was wearing a chain").

In the on-the-stand/pre-trial contradiction condition, the responses of the eyewitness were highlighted by the attorney as inconsistent with previous statements provided by the eyewitness at some point during the investigation (e.g., police reports, depositions). For example, after being asked whether or not the defendant was wearing any 
jewelry, the eyewitness stated that "she remembered the defendant wearing a gold chain." The defense attorney responded: "in a previous deposition you stated the perpetrator was not wearing any jewelry, which is it?" The eyewitness always claimed that her present testimony was accurate (e.g, "I remember he was wearing a chain") .

In the on-the-stand contradiction condition, the responses of the eyewitness were highlighted by the attorney because the eyewitness contradicted herself during the cross-examination. For example, the eyewitness stated early in her testimony that the perpetrator was not wearing any jewelry. Upon further questioning, the eyewitness stated that the perpetrator was wearing a gold chain. The defense attorney responded by stating to the eyewitness "you stated earlier in your testimony that the perpetrator was not wearing any jewelry, which is it?" The eyewitness then responded with the more recently stated information (e.g, "I remember he was wearing a chain"). The on-the-stand contradiction condition was the only manipulation in which subjects heard both contradictions spoken by the eyewitness. Dependant Measures

The questionnaire included a dichotomous verdict (not guilty $v$. guilty) and a series of rating scales. Three items were designed to assess defendant culpability: probability that the defendant committed the crime $(0=10 \mathrm{w}$ 
probability; 6 = high probability) and strength of the prosecution's and defense's cases $(0=$ very weak; $6=$ very strong). Eight items were designed to assess effectiveness of the eyewitness: credibility, consistency, confidence, accuracy, likability, honesty, appearance of confusion, and trustworthiness of the eyewitness. Responses to these items were recorded on scales ranging from 0 (not very [credible, trustworthy, etc.]) to 6 (very [credible, trustworthy, etc.]). Subjects also responded to questions about prior experience as a crime victim and juror and other miscellaneous characteristics and reactions to the trial.

\section{Results}

Standardized effect-sizes for all comparisons are displayed in Table 1 (see pp. 29).

Verdict

Overall conviction rate was $37 \%$ across conditions. A 2 (Subject Type) X 4 (Inconsistency Condition) log-linear analysis of verdict revealed that community members convicted the defendant at a significantly higher rate than did college students $\left(46 \%\right.$ v. $32 \%, x^{2}(1, \underline{N}=300)=6.76, \underline{p}<$ .01. The main effect for inconsistency condition was also significant $x^{2}(3, \underline{\mathrm{N}}=300)=53.81, \underline{\mathrm{p}}<.001$. The conviction-rates were $69 \%$ for the consistent condition, $37 \%$ for the novel information condition, and $20 \%$ for the on-thestand and on-the-stand/pre-trial contradiction conditions. 
Bonferroni post-hoc comparisons using an alpha level of .05 revealed that conviction-rates in all three inconsistency conditions differed significantly from the consistent condition. Contrary to my hypothesis, conviction-rate did not differ between the on-the-stand and on-the-stand/pretrial contradiction conditions. The difference in conviction-rate between the novel information condition and the contradictory conditions was in the expected direction and appreciable in magnitude but statistically nonsignificant. The subject Type $x$ Inconsistency condition interaction was non-significant $x^{2}(3, \underline{N}=300)=1.37, \underline{p}>$ .05 , indicating that college students' and jury eligible community members verdicts were comparably influenced by inconsistent testimony.

Defendant culpability

Means for individual items were 3.20 for probability that the defendant committed the crime, 3.02 for strength of the prosecution's case, and 3.08 for strength of defense case. The three items assessing defendant culpability were highly intercorrelated (Coefficient Alpha $=.80 ;$ corrected item-total correlations ranged from .52 to .72). Given the high level of internal consistency, I recoded the one negatively keyed item and averaged responses to the three items to form a scale labelled defendant culpability. A higher score indicates greater defendant culpability. 
A 2 (Subject-Type) X 4 (Inconsistency Condition) ANOVA on defendant culpability produced a significant main effect for subject-type $\underline{F}(1,292)=5.17, \underline{p}<.05$. Community members found the defendant more culpable $(\underline{m}=3.29)$ than did the student sample $(\underline{m}=2.92)$.

The main effect for inconsistency was also significant, $\underline{F}(3,292)=15.60, \underline{p}<.001$. Defendant culpability was perceived as highest in the consistent condition $(\underline{m}=3.83)$, significantly lower in the novel information condition ( $\underline{m}=$ 3.22), and significantly lower still in the on-thestand/pre-trial $(\underline{m}=2.58)$ and on-the-stand $(\underline{m}=2.56)$ contradiction conditions, with the latter two means not differing significantly from one another. These conclusions were based on Bonferroni post-hoc analyses with an alpha level of .05. The subject-Type $x$ Inconsistency condition interaction was non-significant, $\underline{F}(3,292)=.935, \underline{p}>.05$, indicating that students' and jury eligible community members' culpability ratings were comparably influenced by inconsistent testimony.

Effectiveness of the Eyewitness

Means for the eight items assessing effectiveness of the eyewitness ranged from 2.59 (perceived eyewitness consistency) to 4.06 (perceived eyewitness confidence). These items were found to be internally consistent (Coefficient Alpha $=.92$; corrected item-total correlations 
ranged from .57 to .85$)$; consequently, I recoded negatively keyed items and averaged responses to the eight items to form a single scale titled eyewitness effectiveness. A higher score indicates greater perceived effectiveness.

A 2 (Subject-Type) X 4 (Inconsistent condition) ANOVA on eyewitness effectiveness produced a significant main effect for subject type, $\underline{F}(1,292)=6.01, \underline{p}<.05$. Community members rated the eyewitness as more effective ( $\underline{m}$ $=3.62)$ than did the student sample $(\underline{m}=3.25)$.

The main effect for inconsistency condition was also significant, $\underline{F}(3,292)=26.89 \underline{p}<.001$. Bonferroni posthoc analyses with an alpha level of .05 revealed that the eyewitness was seen as most effective in the consistent condition $(\underline{m}=4.34)$, significantly less effective in the novel information condition $(\underline{m}=3.55)$, and significantly less effective still in the on-the-stand/pre-trial ( $\underline{m}=$ $2.91)$ and on-the-stand $(\underline{m}=2.71)$ contradiction conditions, with the latter two means not differing significantly from one another. The subject Type $\mathrm{X}$ Inconsistency Condition interaction was non-significant, $\underline{F}(3,292)=1.45$, showing that students' and community members' eyewitness effectiveness ratings were comparably influenced by inconsistency condition. 


\section{Prior Jury Experience}

Community members were significantly more likely to have served on juries than were students $(29 \% \mathrm{v} .7 \%), x^{2}(1$, $\underline{N}=300)=27.43, \underline{p}<.001$. Subjects who served on juries, as compared to those with no prior jury service, were more likely to convict $\left(52 \%\right.$ v. $35 \% x^{2}(1, \underline{N}=300)=4.94, \underline{p}<$ $.05)$, perceived the defendant as more culpable (3.62 v. $2.96, \underline{F}(1,295)=7.83, \underline{p}<.01)$ and regarded the eyewitness as more effective $(3.84$ v. 3.31, $\underline{F}(1,295)=5.34, \underline{p}<.05)$.

This pattern of findings suggests the possibility that the main effects observed for subject type could have been a function of prior jury service. In order to test this possibility, verdict, defendant culpability and eyewitness effectiveness were regressed separately over prior jury service (Step 1) and subject type (Step 2). In each of the three analyses, when the variance in the dependent variable associated with prior jury service was extracted, subject type was no longer a significant predictor (partial $r=.10$ for verdict, .08 for defendant culpability, and .09 for eyewitness effectiveness, $\underline{p}>.05$ for each). This suggests that prior jury service might explain the main effects for subject type.

\section{Discussion}

Community members consistently reached more proprosecution decisions as compared to students. When prior 
jury service, which was also associated with pro-prosecution decisions, was controlled for, the main effects for subject type became non-significant. The interaction between subject type and inconsistency condition was non-significant in all tests, implying that community members and students were comparably influenced by inconsistent testimony. The lack of floor and ceiling effects further supports our interpretation of the non-significant interactions. These findings are consistent with the results of post-trial interviews (Broeder; 1965), archival analyses (Dillehay \& Nietzel, 1985; Werner, Strube, Cole, \& Kagehiro, 1985) and survey research (Reed; 1965) showing that prior jury experience is associated with pro-prosecution attitudes and with studies showing that community members and students are comparably influenced by variations in eyewitness testimony (Cutler et al., 1989, 1990) and other trial manipulations (Platania, 1995).

Subjects exposed to any form of inconsistency, as compared to those exposed to consistent testimony, were significantly less likely to convict and perceived the defendant as less culpable and the eyewitness as less effective. As predicted, contradictions, whether between on-the-stand statements or between on-the-stand and pretrial statements, had a greater effect than did information provided on the stand but not in pre-trial investigations. 
These differences were significant in tests of defendant culpability and eyewitness effectiveness. The difference was non-significant but appreciable in magnitude and in the expected direction for verdict -- a dichotomous and therefore less statistically sensitive dependent measure.

Results of this study compliment the earlier results of Berman et al. (1995), who studied the impact of contradictions between on-the-stand and pre-trial statements. They also compliment the results of Leippe and Romanczyk (1989), who found that inconsistent testimony (consisting of both on-the-stand/pre-trial contradictions and on-the-stand statements not mentioned in pre-trial interviews) diminished the credibility of the child eyewitness. In contrast, Leippe and Romanczyk (1989) found that the inconsistent testimony did not influence verdict nor credibility of the adult eyewitness. These results are difficult to compare to Lindsay et al. (1986), as they assessed the impact of yet a different kind of inconsistency, to wit, a contradiction between a description of the perpetrator and the physical characteristics of the defendant identified from the lineup.

As mentioned earlier, there is little social-cognitive psychological theory that directly explain these results. Given the potential ecological importance of these findings, 
more attention should be paid to theoretical explanations (assuming, of course, that these findings replicate).

One related phenomenon is the discounting hypothesis (Kelley, 1972): the presence of other potential causes for a behavior (referred to as discounting cues) leads observers to attach less importance to any given cause for that behavior. Consider, for example, the differences observed between the novel information and on-the-stand contradiction conditions. When subjects are presented with statements on the witness stand that were not given during pretrial investigation, they may reason that other explanations exist for the novel information. Many explanations exist, such as the previous investigator, in the pre-trial interview, did not inquire about the novel information or asked questions in such a way as to not elicit certain information. During pre-trial investigation the eyewitness or the investigator may not have thought that the information presented later in court was important enough to mention. These explanations do not necessarily imply faulty memory and they do not apply to on-the-stand contradictions. Thus, if we assume these explanations serve as discounting cues, jurors may be more willing to excuse inconsistencies of the novel information sort than of the on-the-stand contradiction sort. on the other hand, the discounting cues might also support a significant difference between the on-the-stand 
and on-the-stand/pre-trial contradiction conditions. Subjects may be more willing to excuse the on-the-stand/pretrial contradictions because there was a greater time lag between them than between on-the-stand contradictions. Results of the present study do not support this notion. The discounting explanation assumes that jurors are sensitive to factors such as time lag between statements and interview context. This seems unlikely given that jurors appear insensitive to many cognitive and social psychological factors that influence other aspects of eyewitness memory, such as eyewitness identification (Cutler et al., 1990).

Given the findings of the present and previous studies (particularly Berman et al., 1995), it is sensible to ask whether inconsistency is, in fact, indicative of inaccuracy. Fisher and cutler (in press) summarized data from four separate studies examining 612 identification attempts of eight different targets. Descriptions of the to-beidentified target persons were obtained on two occasions and were scored for consistency. Identifications were obtained from target-present and-absent photoarrays. Thus, each subject had a score for proportion of consistent statements and a score for identification accuracy. Correlations were computed across subjects but separately for each of the eight targets. These correlations ranged from -.06 to .23 
and averaged only .10. Only two of the correlations were statistically significant. In conclusion, the only npublished data addressing this issue shows that consistency of testimony is not a powerful predictor of eyewitness identification accuracy. It is not clear, therefore, that impeaching eyewitnesses on the basis of inconsistent statements actually improves the quality of juror decisions. Eyewitnesses impeached for giving inconsistent testimony may be no less accurate than eyewitnesses who give consistent testimony.

Further research is needed to understand the relations between consistency and accuracy of eyewitness testimony, how different types of inconsistent statements influence juror decisionmaking, juror sensitivity to factors affecting eyewitness testimony, and theoretical underpinnings of these effects. Of course, it is also important to assess how the effects of inconsistent testimony might be qualified by discussion during jury deliberation. In addition, more research is needed on the frequency with which inconsistencies of the different types appear in court or in other significant legal proceedings and the frequency with which such inconsistencies are exploited. It would also be interesting to know the techniques that attorneys use during re-direct examination to rehabilitate eyewitnesses who have been discredited through inconsistent testimony, the 
frequency with which these techniques are used, and their effectiveness. Relatedly, it is critical to assess the impact of inconsistent statements in more realistic trials. While use of a videotaped trial may represent some improvement over written trial materials (e.g., Leippe \& Romanczyk, 1989) or audiotaped trials (e.g., Lindsay et al., 1986), the gains are modest. Because of length restrictions, the eyewitness testimony may be overemphasized and the effects of inconsistent testimony exaggerated. Field studies involving actual cases would be particularly useful.

Last, identifying inconsistencies is only one strategy that attorneys use in cross-examination of eyewitnesses. It is also reasonable to believe that attorneys focus questions on the factors affecting the eyewitness's ability to encode information at the time of the crime and retrieve or recognize crime details later. Unfortunately, as mentioned earlier, there is little research on attorneys' actual practices in cross-examination. Trial simulation studies of juror sensitivity to encoding and retrieval factors reveal that even when many such factors are brought to their attention in cross-examination, subjects tend to ignore them (Cutler et al., 1990) unless subjects are guided by expert psychological testimony explaining how these factors influence eyewitness memory (Cutler et al., 1989). 
Furthermore, there is evidence that attorneys themselves are not sensitive to some important factors affecting eyewitness memory (Brigham \& Wolfskeil, 1983; stinson et al., 1995). Trial simulation studies further show that, when left to their own devices, subjects base their decisions on factors that appear to have questionable associations with identification accuracy, including confidence, level of detail in testimony, accuracy of peripheral details and consistency of testimony, (Bell \& Loftus, 1989; Cutler et al., 1990; Fisher \& Cutler, in press; Lindsay, Wells, \& O'Connor, 1989; Lindsay, Wells, \& Rumpel, 1981; Wells \& Leippe, 1981; Wells, Lindsay, \& Ferguson, 1979).

Consequently, further research should focus on using psychological theory to enhance the effectiveness of crossexamination as a safeguard. Further research should also examine the impact of other existing safeguards and devise new, effective safeguards for protecting defendants from erroneous conviction resulting from mistaken eyewitness identification. 
References

Bailey, F. L., \& Rothblatt, H. B. (1985). Successful techniques for criminal trials. Rochester NY: Lawyers co-operative.

Bell, B. E., \& Loftus, E. F. (1989). Degree of detail of eyewitness testimony and mock juror judgment. Journal of Applied Social Psychology, 18, 1171-1192.

Berman, G. L., Narby, D. J., \& Cutler, B. L. (1995). Effects of inconsistent eyewitness statements on mockjurors' evaluations of the eyewitness, perceptions of defendant culpability and verdicts. Law and Human Behavior, 1, 79-88.

Borchard, E. (1932). Convicting the innocent: Errors of criminal justice. New Haven: Yale University Press.

Brandon, R., \& Davies, C. (1973). Wrongful imprisonment. London: Allen \& Unwin.

Brigham, J. C., \& Wolfskeil, M. P. (1983). Opinions of attorneys and law enforcement personnel on the accuracy of eyewitness identification. Law and Human Behavior, 7, 337349 .

Broeder, D. W. (1965). Previous jury trial service affecting juror behavior. Insurance Law Journal, 506, 138143. 
Cutler, B. L., Dexter, H. R., \& Penrod, S. D. (1989). Expert testimony and jury decision making: An empirical analysis. Behavioral Sciences and the Law, 7, 215-225.

Cutler, B. L., Dexter, H. R. \& Penrod, S. D. (1991). Nonadverserial methods for improving juror sensitivity to eyewitness evidence. Journal of Applied Social Psychology. 20, 1197-1207.

Cutler, B. L. \& Penrod, S. D. (1995). Mistaken Identification: The Eyewitness, Psychology and the Law. York: Cambridge University Press.

Cutler, B. L., Penrod, S. D., \& Dexter, H. R. (1990). Juror sensitivity to eyewitness identification evidence. Law and Human Behavior, 14, 185-191.

Dillehay, R. C., \& Nietzel, M. T. (1985). Juror experience and jury verdicts. Law and Human Behavior, 9 , 179-191.

Fisher, R. P., \& Cutler, B. L. (in press). Relation between consistency and accuracy of eyewitness testimony. In G. M. Davies, Lloyd-Bostock, S., McMurran, M., \& Wilson, c. (Eds.), Psychology and Law: Advances in Research. Berlin: De Gruyter.

Frank, J., \& Frank, B. (1957). Not quilty. London: Gallancz . 
Greene, E. (1988). Judge's instruction on eyewitness testimony: Evaluation and revision. Journal of Applied Social Psychology, 18, 252-276.

Kassin, S. M. (1985). Eyewitness identification: Retrospective self-awareness and the confidence-accuracy correlation. Journal of Personality and Social Psychology, 49, 878-893.

Kelley, H. H. (1972). Attribution in social interaction. In E. E. Jones, D. E. Kanouse, H. H. Kelley, R. E. Nisbett, S. Valins, \& B. Weiner (Eds.), Attribution: Perceiving the causes of behavior (pp. 1-26). Morristown, NJ: General Learning Press.

Konecni, V. J., \& Ebbesen, E. B. (1979). External validity of research in legal psychology. Law and Human Behavior, 3, 39-70.

Leippe, M. R., \& Romanczyk, A. (1989). Reactions to child (versus adult) eyewitnesses: The influence of jurors' preconceptions and witness behavior. Law and Human Behavior, 13, 103-132.

Lindsay, R. C. L., Lim, R., Marando, L., \& Cully, D. (1986). Mock-juror evaluations of eyewitness testimony: A test of metamemory hypotheses. Journal of Applied Social Psychology, 16, 447-459. 
Lindsay, R. C. L., Wells, G. L., \& O'Connor, F. J. (1989). Mock juror belief of accurate and inaccurate eyewitnesses: A replication and extension. Law and Human Behavior, 13, 333-339.

Lindsay, R. C. L., Wells, G. L., \& Rumpel, C. M. (1981). Can people detect eyewitness identification accuracy within and across situations? Journal of Applied Psychology, 66, 79-89.

Malpass, R. S., \& Kravitz, J. (1969). Recognition for faces of own and other race. Journal of Personality and Social Psychology, 13, 330-334.

People v. McDonald, 37 Cal. 3d 351, 208 Cal. Rptr. 236 (1984) •

Platania, J. (1995). Prosecutorial misconduct promotes wrongful death sentences. Unpublished doctoral dissertation, Florida International University, Miami.

Prager, I. R., Moran, G., \& Sanchez, J. (1992). Assistant Public Defenders: Job analysis project. Manuscript submitted for publication.

Rattner, A. (1988). Convicted but innocent: Wrongful conviction and the criminal justice system. Law and Human Behavior, 12, 283-293.

Reed, J. P. (1965). Jury deliberations, voting, and verdict trends. Southwestern Social Science Quarterly, 45 , $361-370$, 
Stinson, V., Devenport, J. L., Cutler, B. L., \& Kravitz, D. K. (1995). How effective is the presence-ofcounsel safeguard? Attorney perceptions of suggestiveness, fairness, and correctability of biased lineup procedures. Manuscript submitted for publication.

U.S. V. Telfaire, 469 F. 2d 552, 558-559 (1972).

U.S. V. Wade, 388 U.S. 218 (1967) .

Walters, C. M. (1985). Admission of expert testimony on eyewitness identification. California Law Review, 73, 1402-1430.

Weiten, W., \& Diamond, S. S. (1979). A critical review of the jury simulation paradigm: The case of defendant characteristics. Law and Human Behavior, 3, 71-93.

Wells, G. L., \& Leippe, M. R. (1981). How do triers of fact infer the accuracy of eyewitness identifications? Using memory for peripheral detail can be misleading. Journal of Applied Psychology, 66, 682-687.

Wells, G. L., Lindsay, R. C. L., \& Ferguson, T. J. (1979). Accuracy, confidence, and juror perceptions in eyewitness identification. Journal of Applied Psychology, 64, 440-448.

Werner, C. M., Strube, M. J., Cole, A. M., \& Kagehiro, D. K. (1985). The impact of case characteristics and prior jury experience on jury verdicts. Journal of Applied Social Psychology, 15, 409-427. 
Table 1

Standardized Effect-Sizes (d) for Pairwise Comparisons of Consistency Condition Means

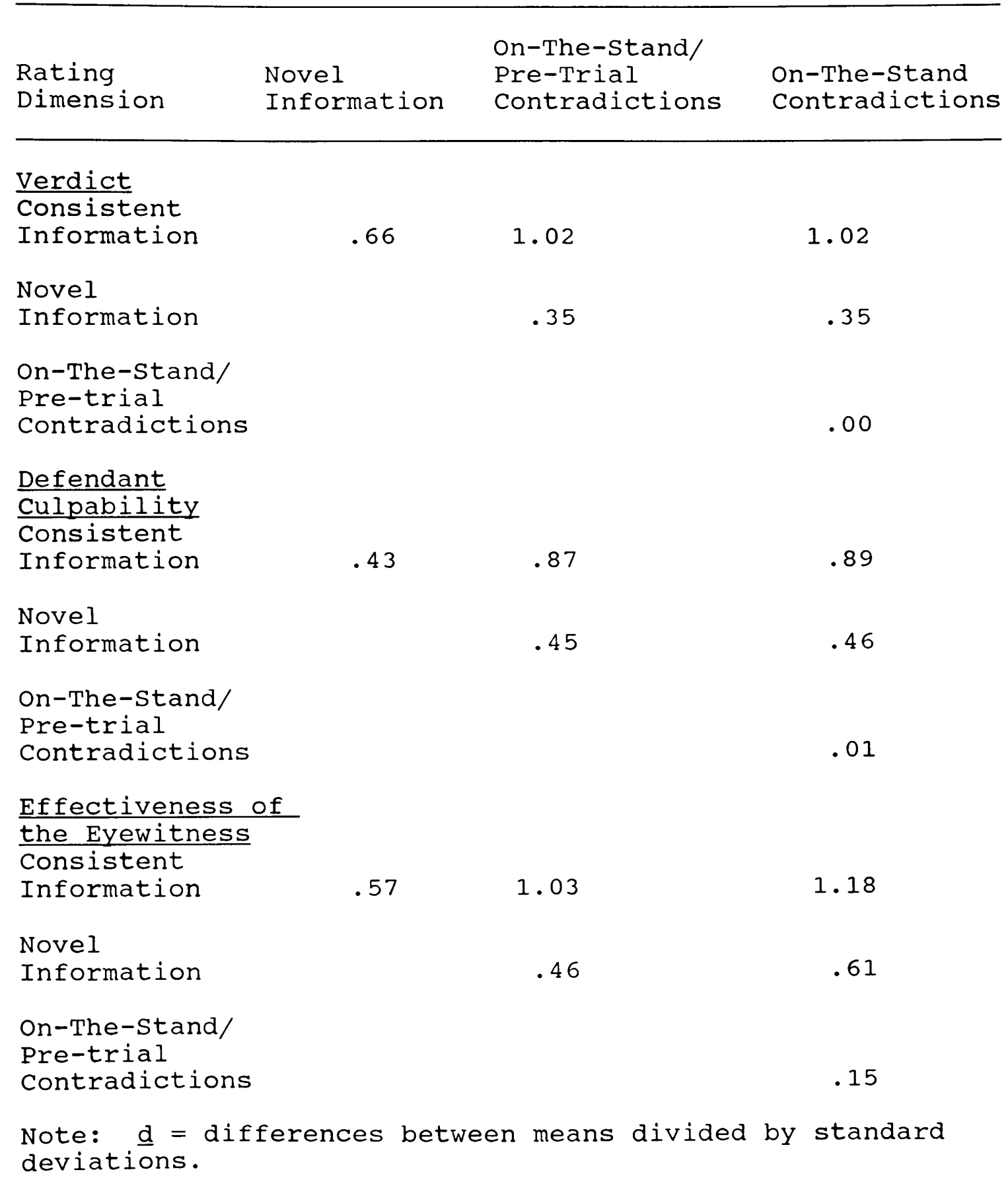




\section{Appendix}

\section{OPENING STATEMENT FOR PROSECUTION}

May it please the court. Today, ladies and gentlemen, we are here for one reason and one reason only, on Friday at approximately 9 in the morning, Mr. Jones, armed with a gun, robbed the Glendale Federal Bank in Ft. Lauderdale, Florida. Good morning ladies and gentlemen, my name is Mrs. Waters and I work as a prosecutor for the Broward County state Attorneys' office. The evidence will show and we will prove beyond a reasonable doubt through eyewitness testimony that Mr. Jones committed this heinous crime. Now, although we the state have the burden of proof in this case, we are very confident that you will render the only verdict that speaks the truth, a verdict of guilty of armed robbery.

\section{OPENING STATEMENT FOR DEFENSE}

Mistaken identity. Let me say that again. Mistaken identity! Hello, ladies and gentlemen, my name is Mrs. Daley and I represent Mr. Jones in this case. When I first stood before you, I said the phrase Mistaken Identity. This case involves the concept of mistaken identity and how someone can think they see something when they actually do not. The evidence in the case will show that Mr. Jones was not in the bank at the time of the robbery. Moreover, the defense will show that Mr. Jones was not the man who robbed the bank. Now ladies and gentlemen, we agree with the state 
that this was a heinous crime and someone should be punished. But, ladies and gentlemen, that someone is not Mr. Jones. Keep in mind throughout this trial that the state bears the burden of proof. They must prove beyond and to the exclusion of any reasonable doubt that Mr. Jones committed this crime. I am confident that after you listen to all the testimony and take into consideration all the evidence, you will find Mr. Jones not guilty of armed robbery.

\section{Direct Examination of Dawn Mitchell (the Eyewitness)} JUDGE: Today we are hearing evidence in the case of the State of Florida v. Gary Jones. The defendant, Mr. Jones is accused of robbery. Mrs. Waters (prosecuting attorney) would you like to call your first witness?

A. Yes, your honor, the state would like to call Dawn Mitchell to the stand.

Q. Dawn, my name is Mrs. Waters and, I'm the prosecuting attorney. There's some questions that I want to ask you concerning the robbery at your bank. If there is any time during questioning you become confused, please inform me. I'm here to find out what the truth is. If you don't know something I want you to answer that you don't know, or you are not sure. If you are sure, then you answer it that way.

$$
\text { A. okay. }
$$


Q. Would you state you full name, please?

A. Dawn Leeann Mitchell.

Q. Dawn, where do you work?

A. Glendale Federal Bank, on Broward Blvd.

Q. How long have you worked there?

A. Seven years.

Q. And what are your duties there?

A. I am the head teller.

Q. What does that involve?

A. I run the daily operations

of the teller department, assist customers, and research outages, basic supervisory duties.

Q. Who do you work most closely with?

A. Amy Peters and Nancy Taylor.

Q. And how long have you worked with

Amy for?

A. She's been there for about 5 years.

Q. What about Nancy Taylor?

A. She is the branch manager. She's been there a few months. She came in April.

Q. And she was just there a short time before the incident happened, correct?
A. Yes.
Q. As part of your training and

working for the bank, are you trained what to do if 
somebody comes to your teller window and demands money?
A. Yes, we are.
Q. And what is your training?
A. Normally they tell you to give them whatever they ask for. If they tell you not to give bait money, you don't give the bait money. If they tell you not to pull the alarm, you don't do that. Basically you give them what they want so they leave.

Q. Have you ever been robbed before?

A. Me, personally, no. But one of my tellers has been robbed.

Q. Were you a witness to this?

A. Yes. They didn't catch them so it didn't go any further than that.

Q. Were you able to give a description of the person?
A. Yes.
Q. And did you give a description?
A. Yes.
Q. Did you feel the description was

accurate?
A. Yes.
Q. Is it the same bank that was robbed?
A. Yes.
Q. When was that? 
A. It was about two years ago.

Q. Was a note given in the other

incident?

A. No.

Q. I'd like to now discuss the particular robbery in question. Do you recall what day of the week it was?
A. It was a Friday.
Q. Do you recall what time the incident

took place?

A. Right when the doors opened at 9 o'clock.

Q. Tell me what happened.

A. Well, that day I was the only person at the window because I had two tellers out sick. And right when the doors opened, he entered the bank. I looked at him and I recognized who he was.

Q. At this point, what were you doing?

A. I was counting my drawer.

Q. So you looked up?

A. Yes, I looked, and I saw him and waited for him to come around.

Q. How long did you look at him when he entered the bank?

A. Three seconds. 
Q. Did the man have a baseball cap and sunglasses on?

$$
\text { A. Yes. }
$$

Q. And yet you recognized him when he came through the door?
A. Yes.

Q. How?

A. Because I know who he is. He's kind of a strange individual.

Q. In what way is he strange?

A. There is no one type of a mannerism that I could pick out. But for instance, he had a lot of money in this one account and he kept withdrawing money out of the account and the service charge is ten dollars a month. We told him to change it over to his other account so he doesn't get the service charge but he didn't want to do it. It's kind of strange that somebody would want to pay ten dollars a month for no reason.

Q. How did you recognize the perpetrator as being Mr. Jones?

A. He's one of our customers.

Q. Well, the man that came through the door had a cap and sunglasses on. How did you 
recognize him to be Mr. Jones? Does $\mathrm{Mr}$. Jones always wear a cap and sunglasses?

A. He doesn't always wear sunglasses. On

a few occasions he's worn a hat.

Q. What feature was it that led you to believe it was Mr. Jones?

A. No particular feature, it's his general appearance.

Q. So you are describing what got your attention that it was Mr. Jones was his general demeanor?

A. Yes.

Mrs. Waters: No further questions your Honor. Judge: Mrs. Daley, would you like to question the witness?

Mrs. Daley: Yes, thank you, your honor.

\section{Cross-Examination of Dawn Mitchell}

Q. Good afternoon, Dawn. I represent Mr. Jones in this case and would like to ask you some questions regarding the robbery at the bank in which you work. Are you are currently working at the same Glendale Federal Bank that was robbed?

A. Yes. 
Q. Dawn, you were an eyewitness to the robbery that occurred at Glendale Federal Bank, is that correct?

A. Yes.

Q. Do you have any vision problems?

A. No, I don't.

Q. And you don't wear glasses?

A. No, I don't.

Q. Contacts?

A. No.

Q. When was the last time you had your eyes checked?

A. About two months ago. I got something in my eye and they checked it out but my vision was perfect.

Q. How about your memory, your ability

to recall?

A. No problems.

Q. What happened next?

A. He came to my window.

Q. Then what happened?

A. He had a canvas bag that he sat on the teller window. And he had a note underneath it and he pushed it like this [hand gesture], with his hand on the note. I was trying to look at the note because a 
lot of times customers write down how they want their change but he grabbed it away pretty fast. The only thing I saw was eight hundred written on the note.

\section{[PAUSE]}

He was soft-spoken and calm.

\section{[PAUSE]}

He told me to give him the money. He was sweating a lot,

\section{[PAUSE]}

and he seemed nervous.

\section{[PAUSE]}

And at that point, I knew I was being robbed.

\section{[PAUSE]}

Q. Was the perpetrator wearing any jewelry? For example, a watch?

A. No.

\section{[PAUSE]}

Q. How come you didn't mention that he seemed nervous during any of your previous statements?

A. I remember he appeared nervous [PAUSE]

Q. What happened next?

[PAUSE] 
Q. Didn't you previously state at the crime scene that the perpetrator was calm throughout the entire incident?
A. I remember he appeared nervous
Q. What happened next?

[PAUSE]

A. I went to my top drawer which only contains twenties and less and he said, "no, I want hundreds." I then went to my second drawer to get out the hundreds. I broke out a strap of hundreds and I gave it to him.

\section{[PAUSE]}

He said, "I have a gun I'll shoot you, give me more."

[PAUSE]

That's when I saw something sticking out from underneath his shirt. So at that point I gave him the rest of the money

\section{[PAUSE]}

he threw it into his bag

\section{[PAUSE]}

and he left.

Q. Did you notice Amy Peters around there anywhere?

A. Yes. Apparently she was asking Nancy if she knew the customer. 
Q. How long would you say it took the

whole thing to go down?

A. Three minutes.

Q. And how close did Amy get to him?

A. About seven feet.

Q. Was she in a position to ever see his

face?

A. Yes, when he walked through the door.

Q. Did you notice any distinguishing features on his face, like birthmarks, scars, or moles?

A. No.

Q. Did he have a mustache?

A. No.

Q. Are you sure of that?

A. Yes.

Q. What was his facial hair like?

A. He was clean shaven.

Q. What was he wearing?

A . He was wearing a baseball cap,

and sunglasses that were tinted brown, and he had on jeans, and a jacket.

Q. What color was the jacket?

A. It was a dark colored jacket.

Q. Is that what he normally wears when he comes into the bank? 
A. No. He normally wears scrub gear

that people wear for surgery.

Q. When you say scrub gear, you are talking about the hospital type gear, is that right?

A. Yes.

\section{[PAUSE]}

Q. What was his demeanor like during the

robbery?

A. He appeared to be nervous.

Q. Just moments ago, you stated he was soft-spoken and calm. Which is it? Was he nervous or calm?

A. He appeared nervous

Q. Did he threaten you at any point?

A. No.

Q. Earlier in your testimony you stated that he said he would shoot you if you didn't give him more money.

A. He did not threaten me.

\section{[PAUSE]}

Q. Did he threaten you at any point?

A. No.

Q. In a previous deposition, you stated that he threatened your life if you didn't give him the money • 
A. He did not threaten me.

[PAUSE]

Q. Did he threaten you at any point?

A. No, he did not threaten me.

Q. How come you never mentioned this point in any of your previous statements during the investigation?

A. He did not threaten me.

[PAUSE]

Q. Did the police have you make an identification?

A. Yes.

Q. Where did you make this identification?

A. Where Mr. Jones works.

Q. When you saw him at his place of work, what was he wearing?

A. He had changed his clothes to a white shirt and a pair of dark pants.

Q. You previously stated that the perpetrator was wearing sunglasses that were tinted brown. Were they the same sunglasses the police showed you?

A. Yes, they looked the same.

Q. Would you say you got a good look at the perpetrator? 
A. Yes.

Q. Could you see the color of his eyes?

A. No, not with his glasses on.

Q. What type of jacket did he have on?

A. It was a dark denim jacket with a pocket on the inside. That's where he put the money.

\section{[PAUSE]}

Q. During the investigation you provided numerous statements. You never mentioned that he put the money in his jacket pocket before.

A. I remember he put the money inside his jacket pocket.

\section{[PAUSE]}

Q. In a previous statement at the crime scene, you stated that the perpetrator stuffed all the money into a canvas bag.

A. He put the money inside his jacket pocket.

\section{[PAUSE]}

Q. Earlier, you mentioned that he put all the money in a canvas bag. Which is it?

A. He put the money inside his jacket pocket.

\section{[PAUSE]}

Q. What type of hat did he have on? 
A. A baseball cap.

Q. What color was the baseball cap?

A. It was dark blue.

Q. Did it have anything on it?

A. There was something embroidered on the front.

Q. When did you notice something was embroidered on the front?

A. When he came up to my window.

[PAUSE]

Q. Did you notice any jewelry, watches?

A. Yes, he was wearing a gold chain.

Q. You stated earlier in your testimony that the defendant was not wearing any jewelry, which is it?

A. I remember he was wearing a chain. [PAUSE]

Q. Did you notice any jewelry, watches?

A. Yes, he was wearing a gold chain.

Q. How come you never mentioned any jewelry in previous depositions?

A. I remember he was wearing a chain.

[PAUSE]

Q. Did you notice any jewelry, watches?

A. Yes, he was wearing a gold chain 
Q. In a previous deposition you stated the perpetrator was not wearing any jewelry, which is it?

A. I remember he was wearing a chain.

[PAUSE]

Q. When the police brought you to identify Mr. Jones did he look exactly like the bank robber?

A. He changed his appearance a little bit from what he looked like the morning of the robbery. He was not wearing his hat. And of course he changed his clothes.

Q. Now, Dawn, you are making a lot of assumptions, aren't you?

A. In regard to what?

Q. That he changed his clothes. You don't know he changed his clothes.

A. I know he changed from what he was wearing when he came in to rob me.

Q. It might be that you are assuming that Mr. Jones robbed you and it wasn't Mr. Jones?

A. No, because I recognized him when he came in the door as being our customer, Mr. Jones. Q. You are convinced that this was Mr. Jones aren't you?

A. Yes, I am. 
Q. And nothing is going to change you

mind?

A. No.

Q. What about the fact that you gave a general description of the man that was standing in front of you?

A. Because I recognized him when he came in as being our customer, Mr. Jones.

Q. I don't mean to be rude but that's an easy way out don't you think, "I recognized him when he came in?"

A. No, because I know his face. I know what he looks like.

Q. And you've never made a mistake about identifying a person before?

A. Not to my knowledge.

Q. Never seen two people that look alike?

A. Of course a lot of people look alike.

Q. Ever mistaken one person for another?

A. Yes, hasn't everyone?

Thank you your Honor I have no further questions Direct Examination of Phil watts (neutral defense witness) Occupation: Manager of Milton Manor Apartments Relationship to defendant (Mr. Jones): Mr. Jones' landlord Questioning conducted by Mrs. Daley (defense attorney): Q. Please state your name for the court. 

A. Phil Watts.
Q. Please state your occupation Mr. Watts.
A. I manage Milton Manor apartments in Fort

Lauderdale.

Q. Please state the full address.

A. 101 East Commercial Blvd.

Q. Do you know the defendant Mr. Jones?

A. Yes.

Q. What is your relationship with Mr. Jones?

A. I'm his landlord.

Q. How long has Mr. Jones been living at

Milton Manors?

A. About 2 years.

Q. When did you first meet the defendant $\mathrm{Mr}$.

Jones?

A. When I rented him the apartment 2 years ago.

Q. Has he ever caused any sort of disturbance in the building?

A. Not that I'm aware of.

Q. Does he ever play loud music?

A. No.

Q. Does he get along with the other tenants?

A. Yes, as far as I know.

Q. Would you say that Mr. Jones is a good 
tenant?

A. Yes.

Q. Could you elaborate on what you believe is a "good tenant?"

A. Mr. Jones is a quiet person. He has never caused me or any of the other tenants problems.

Q. What about the rent? Does Mr. Jones normally pay the rent on time?

A. Always.

Q. How much rent does Mr. Jones pay a month?

A. $\$ 600.00$

Q. Did Mr. Jones ever need an extension?

A. No.

Q. So his finances, as far as you know, are stable and sufficient enough to at least pay the necessities like rent each month?

A. Yes.

Q. So what you are saying is $\mathrm{Mr}$. Jones is an ideal tenant?

A. Yes.

Q. No further questions your Honor Judge to Prosecutor: Mrs. Waters, do you have any questions for Mr. Watts? 
Cross-Examination of Phil watts (neutral defense witness)

Q. Yes, your honor. Did you know the

defendant before his residence in your building?
A. No.
Q. Have you ever had a lengthy conversation

with him?
A. No.
Q. So you don't know him on a social level?
A. No, not really.
Q. You would not be a good judge of his

character then?
A. I guess not.
Q. Mr. Watts, when Mr. Jones applied for

residency, did you ask for his place of employment?
A. Yes.
Q. Did you verify this?
A. No.
Q. So you do not know if he is or was ever working there?
A. Not directly.
Q. Did you ever contact his required

references?
A. No.
Q. If you don't know about his history or his present state of affairs, you cannot then compose 
opinions about Mr. Jones. How can you recognize this man from any other residing in your building, let alone from another perpetrator?

A. I know who he is.

No further questions your honor.

Judge: Mrs. Waters, do you have any further questions for the witness?

Mrs. Waters: No further questions, your honor.

\section{CLOSING STATEMENT FOR PROSECUTION}

Ladies and gentlemen of the jury, when I first stood before you at the beginning of this trial, I told you what we, the state, would prove. I told you that we had an eyewitness who would testify to what she saw happen that Friday at the Glendale Federal Bank. You even heard Mrs. Mitchell get up on the stand and say that she knew it was Mr. Jones because she had seen him before. She knew it was him because "he was a regular customer of mine." Now, you just heard the defense say that Mrs. Mitchell was mistaken, of that she was lying. Ladies and gentlemen, I want you to think to yourself what, if anything, does Mrs. Mitchell gain from testifying here today? I am very confident that when you review the evidence and weigh the facts in this case, your decision will be a very easy one. And that decision is a guilty verdict of armed robbery. 


\section{CLOSING STATEMENT FOR DEFENSE}

Mistaken identity. Ladies and gentlemen, at the beginning of this trial you heard the phrase mistaken identity. After listening to the witnesses and looking at the evidence, it is time for you to make a decision. However, before you decide the outcome of this case, I want to remind you of your civil duty to the criminal justice system. Let me point out some highlights of the evidence exposed to you during the trial. I want you to remember when Mrs. Mitchell got up on the stand. I want you also to remember that you are to judge the credibility of the witnesses. Try and remember everything she said about what the culprit was wearing and what he looked like. I want you also to remember that the state must prove beyond and to the exclusion of any reasonable doubt that $\mathrm{Mr}$. Jones committed this crime. Ladies and gentlemen, this is an extremely high burden to meet. I am confident that you will return the only verdict that speaks the truth, a verdict of not guilty.

\section{JUDGES ' INSTRUCTIONS}

Members of the jury, I thank you for your attention during this trial. Please pay attention to the instructions I am about to give you.

STATEMENT OF CHARGE

Gary R. Jones, the defendant in this case, has been accused of the crime of robbery. 


\section{PLEA OF NOT GUILTY; REASONABLE DOUBT; AND BURDEN OF PROOF}

The defendant has entered a plea of not guilty. This means you must presume or believe the defendant is innocent. The presumption stays with the defendant as to each material allegation in the Information through each stage of the trial until it has been overcome by the evidence to the exclusion of and beyond a reasonable doubt.

To overcome the defendant's presumption of innocence the state has the burden of proving the following two elements:

1. The crime with which the defendant is charged was committed.

2. The defendant is the person who committed the crime. The defendant is not required to prove anything. Whenever the words "reasonable doubt" are used you must consider the following: A reasonable doubt is not a possible doubt, a speculative, imaginary or forced doubt. Such a doubt must not influence you to return a verdict of not guilty if you have an abiding conviction of guilt. On the other hand, if, after carefully considering, comparing and weighing all the evidence, there is not an abiding conviction of guilt, or, if, having a 
conviction, it is one which is not stable but one which wavers and vacillates, then the charge is not proved beyond every reasonable doubt and you must find the defendant not guilty because the doubt is reasonable.

It is to the evidence introduced upon this trial, and to it alone, that you are to look for that proof. A reasonable doubt as to the guilt of the defendant may arise from the evidence, conflict int he evidence or the lack of evidence.

If you have a reasonable doubt, you should find the defendant not guilty. If you have no reasonable doubt, you should find the defendant guilty.

\section{WEIGHING THE EVIDENCE}

It is up to you to decide what evidence is reliable. You should use your common sense in deciding which is the best evidence, and which evidence should not be relied upon in considering your verdict. You may find some of the evidence not reliable, or less reliable than other evidence.

You should consider how the witnesses acted, as well as what they said. Some things you should consider are:

1. Did the witness seem to have an opportunity to see and know the things about which the witness testified? 
2. Did the witness seem to have an accurate memory?

3. Was the witness honest and straightforward in answering the attorneys' questions?

4. Did the witness have some interest in how the case should be decided?

5. Does the witness; testimony agree with the other testimony and other evidence in the case?

6. Has the witness been offered or received any money, preferred treatment or other benefit in order to get the witness to testify?

7. Had any pressure or threat been used against the witness that affected the truth of the witness's testimony?

8. Did the witness at some other time make a statement that is inconsistent with the testimony he gave in court?

9. Was it proved that the witness had been convicted of a crime?

10. Was it proved that the general reputation of the witness for telling the truth and being honest was bad? 
You may rely upon your own conclusion about the witness. A juror may believe or disbelieve all or nay part of the evidence or the testimony of any witness.

\section{DEFENDANT NOT TESTIFYING}

The constitution requires the state to prove its accusations against the defendant. It is not necessary for the defendant to disprove anything. Nor is the defendant required to prove his innocence. It is up to the state to prove the defendant's guilt by evidence.

The defendant exercised a fundamental right by choosing not to be a witness in this case. You must not view this as an admission of guilt or be influenced in any way by his decision. No juror should ever be concerned that the defendant did or did not take the witness stand to give testimony in the case.

\section{ROBBERY}

Before you can find the defendant guilty of Robbery, the state must prove the following four elements beyond a reasonable doubt:

1. Gary R. Jones took the money or property described in the charge from the person or custody of Glendale Federal Bank.

2. Force, violence or assault, or putting in fear was used in the course of the taking.

3. The property taken was of some value. 
4. The taking was with the intent to temporarily or permanently deprive Glendale Federal Bank of its right to the property or any benefit from it.

"In the course of the taking" means that the act occurred prior to, contemporaneous with, or subsequent to the taking of the property and that the act and the taking of the property constitute continuous series of acts or events.

In order for a taking of property to be robbery, it is not necessary that the person robbed be the actual owner of the property. It is sufficient if the victim has the custody of the property at the time of the offense. The taking must be by the use of force or violence or by assault so as to overcome the resistance of the victim, or by putting the victim in fear so that he does not resist. The law does not require that the victim of robbery resist to any particular extent or that he offer any actual physical resistance if the circumstances are such that he is placed in fear of death or great bodily harm if he does resist. But unless prevented by fear there must be some resistance to make the taking one done by force or violence.

It is also robbery if a person, with intent to take property from a victim, administers any substance to another 
so that the victim becomes unconscious and then takes the property from the person or custody of the victim.

In order for a taking by force, violence or putting in fear to be robbery, it is not necessary that the taking be from the person of the victim. It is sufficient if the property taken is under the actual control of the victim so that it cannot be taken without the use of force, violence or intimidation directed against the victim.

\section{SUBMITTING CASE TO JURY}

In closing, let me remind you that it is important that you follow the law spelled out in these instructions in deciding your verdict. There are no other laws that apply to this case. Even if you do not like the laws that must be applied, you must use them. For two centuries we have agreed to a constitution and to live by the law. No one of us has the right to violate rules we all share. 
VITA

1990

B.S., Psychology

Cortland college

Cortland, New York

1990-1992: Graduate Teaching Assistant

Department of Psychology

Florida International University

1993

M.S., Psychology

Florida International University

North Miami, Florida

1993-1995: Graduate Adjunct Professor

Department of Psychology

Florida International University

AWARDS AND HONORS

1988 Psi Chi: National Honor Society in Psychology. of student body.

1990 B.S. conferred cum laude

1990 Phi Kappa Phi Honor Society: GPA in top $10 \%$ of the undergraduate senior class.

PUBLICATIONS AND PRESENTATIONS

Berman, G. L., Cutler, B. L., \& Foos, P. W. (1991, June). Attempts to improve face recognition accuracy by inducing holistic processing at retrieval. In D. F. Ross and M. P. Toglia (Chairs), current trends in research on adult eyewitness memory and identification accuracy. 
Symposium presented at the meeting of the American

Psychological Society, Washington, DC.

Caiola, M. L., \& Berman, G. L. (1991, August). Tort reform items in an insurance fraud case. Paper presented at the meeting of the American Psychological Association Annual Meeting, San Francisco, CA.

Berman, G. L., Wagner, J., \& Cutler, B. L. (1992, March). Attempts to improve face recognition accuracy through the matching of encoding and retrieval operations. Paper presented at the meeting of the American PsychologyLaw Society, San Diego, CA.

Narby, D. J., \& Berman, G. L. (1992, March). Development and reliability assessment of a scale to measure attitudes toward eyewitness credibility. Paper presented at the meeting of the American Psychology-Law Society, San Diego, CA.

Caiola, M. L., Berman, G. L., \& Cutler, B. L. (1993, June). Effects of alcohol intoxication and encoding conditions on eyewitness memory. Paper presented at the meeting of the American Psychological Society, Chicago, IL. Allen, S., Cutler, B. L., \& Berman, G. L. (1993, August). Assessment of negotiations for success and resistance to PTSD. Paper presented at the meeting of the American Psychological Association, Toronto, Canada. 
Berman, G. L., Cutler, B. L., Penrod, S. D. \& Fisher, R. P. (1993, August). Eyewitness identification from live, videotaped, or photographic lineups. Paper presented at the meeting of the American Psychological Association Toronto, Canada.

Cutler, B. L., Berman, G. L., Penrod, S. D., \& Fisher, R. P. (1994). Conceptual practical and empirical issues associated with eyewitness identification test media. In D. F. Ross, J. D. Read \& M. P. Toglia (Eds.), Adult Eyewitness Testimony: Current Trends and Developments. (pp. 163-181). London: Cambridge University Press. Berman, G. L., Narby, D. J., \& Cutler, B. L. (1995). Effects of inconsistent eyewitness statements on mockjurors' evaluations of the eyewitness, perceptions of defendant culpability and verdicts. Law and Human Behavior, 19, 79-88. 